\title{
CONVENTIONAL AND SHADOW BANKING SECTOR - COMPARATIVE ASPECTS OF THE POST-CRISIS PERIOD IN TAIM OF THE CURRENCY BOARD - BULGARIA' CASE
}

\author{
Elena Velkova Stavrova ${ }^{1}$
}

\begin{abstract}
The shadow banking or financial institutions specializing in lending whe take an increasingly larger share of today's markets and channels for the movement of financial resources in the markets of resources between economic agents or households.

The main scientific question of this paper is to analyze the reasons of dynamic trends of development of the shadow financial system, and how that contrasts with the conventional model of financial intermediation of commercial banking: "The chains for value creation through credit intermediation that move free financial resources in economic systems for realizing more efficient operations with fewer risks; In non-banking credit intermediation chain trades that take place on weighted average price - and exchange rates in the markets for short-term securities; yield creation in the shadow banking industry are intensively secured strongly which personally are guaranteed both, from individuals and the firms; value chains in the alternative banking system have carried out extensive conventional financial transformation outside the banking system. This means that this type of intermediation converts illiquid, risky fixed assets in "safe" and liquid short-term liabilities."
\end{abstract}

The used methods are: content analysis, and econometrics analysis of empirical databases of the years $2012-2016$ by two financial sectors from BNB

The finding based on the econometrics analyses supports the scientific hypothesis about relations between the process of the increasing role of the informal banking sector, which pushes conventional bank financing due to high credit standards of banking institutions and limited access to finance for individuals who receive their income in the area of the gray economy.

JEL Classification: G21, G23, G28; DOI: http://dx.doi.org/10.12955/cbup.v5.965

Keywords: shadow banking, value chain, financial innovation, financial intermediation

\section{Introduction}

„The rapid development in financial innovations have changed the landscape, for moving free financial resources into the economic system - from savers to individual and corporate investors. Enhanced interference by national and international regulators has restricted innovative creativity and competitive competition between conventional banks by taking additional types of risks. This purposeful intervention has provided additional incentive for these banks to look for an opportunity to secure efficient operations through the development of alternative credit forms whose assets are guaranteed through diversified portfolios. Regulatory arbitrage, limited capital requirements, and postcrisis recovery processes gave further impetus to companies and non-bank credit institutions to provide access for borrowers who would hardly respond to conventional banks' access to credit forms to meet their needs.

Although the shadow banking business is a broad term we use to name nonbank institutions that conduct bank operations, shadow banking is an alternative to the conventional because of the significantly more liberal financial safety net, which otherwise engage conventional banking with the formation of reserves, and the performance of a complex system of regulatory and supervisory rules specified as with national and international banking law.

On the other hand, significant is its role and contribution to improving the competitive environment for increasing the efficiency of the banking business, a process that is stimulated further by the significant losses that the real economy banking industry bore during the global financial and economic crisis (Patonov, 2013; Tanchev, 2015; Tsenkov, 2016 and Tsenkov, 2016).

\section{Body text}

The banking system is critical for the economy as a whole and fluctuations in it are a function of money supply. In this context Minsky's theory about the importance of endogenous money (Ganchev, 2015) in the economic system are critical to the relationship between conventional and alternative shadow banking systems.

\footnotetext{
${ }^{1}$ SWU “Neofit Rilski”-Blagoevgrad, Faculty of Economics, stavrova@swu.bg
} 


\begin{tabular}{|c|c|c|}
\hline Indicator & Conventional banking system & Shadow banking system \\
\hline Capitalization & $10000000 \mathrm{BGLN}$ & 1000000 BGLN \\
\hline Leverage & $\begin{array}{l}\text { State of Maintenance leverage } \\
\text { ratio }\end{array}$ & $\begin{array}{l}\text { State of Maintenance leverage } \\
\text { ratio not less than the statutory } \\
\text { capital }\end{array}$ \\
\hline Financing & Stocks, deposits & Stocks, shares \\
\hline Liquidity & $\begin{array}{l}\text { State of Maintenance liquidity } \\
\text { ratio }\end{array}$ & $\begin{array}{l}\text { State of Maintenance liquidity } \\
\text { ratio not less than the statutory } \\
\text { capital }\end{array}$ \\
\hline Manager's skill & $\begin{array}{l}\text { Skills for managing financial } \\
\text { institution }\end{array}$ & $\begin{array}{l}\text { Skills for managing financial } \\
\text { institution }\end{array}$ \\
\hline Type of operations & Full range of banking services & $\begin{array}{l}\text { Financial leasing, warranty deal, } \\
\text { factoring, forfeiting, } \\
\text { Acquisition of holdings in a credit } \\
\text { institution or other financial } \\
\text { institution; lending with funds not } \\
\text { raised through public attraction of } \\
\text { deposits or other repayable funds. }\end{array}$ \\
\hline Monitoring & $\begin{array}{l}\text { Every } 3 \text { month reporting, } \\
\text { annually reporting }\end{array}$ & $\begin{array}{l}\text { Every month reporting, annually } \\
\text { reporting }\end{array}$ \\
\hline Numbers & 27 & 179 \\
\hline Monitoring & Chartered by Central bank & Register in Central bank \\
\hline
\end{tabular}

The structure characteristics of the Bulgarian non-banking sector of credit institutions is the representation of both national and mixed - national and international capital, of which - 179 credit intermediaries with national capital, Improving the business environment and profit growth in the financial sector is likely to reduce the projected demand for debt to finance investments and simultaneously stimulate further investment attitudes of the business. This resource is not included in economic turnover and expects profitable future investment projects. Given that endogenous money is closest to the activities of banks that create demand, they limit short-term loans to individuals and businesses. This economic recovery in investment banking, where it is investing internal resources of retained earnings, but in conventional commercial banking or the process this happens slowly, because the return on investment through cost of labor or wages and household consumption take place with lags in time. So, to finance investments empirical reality shows that firms take on new debt to finance assets.

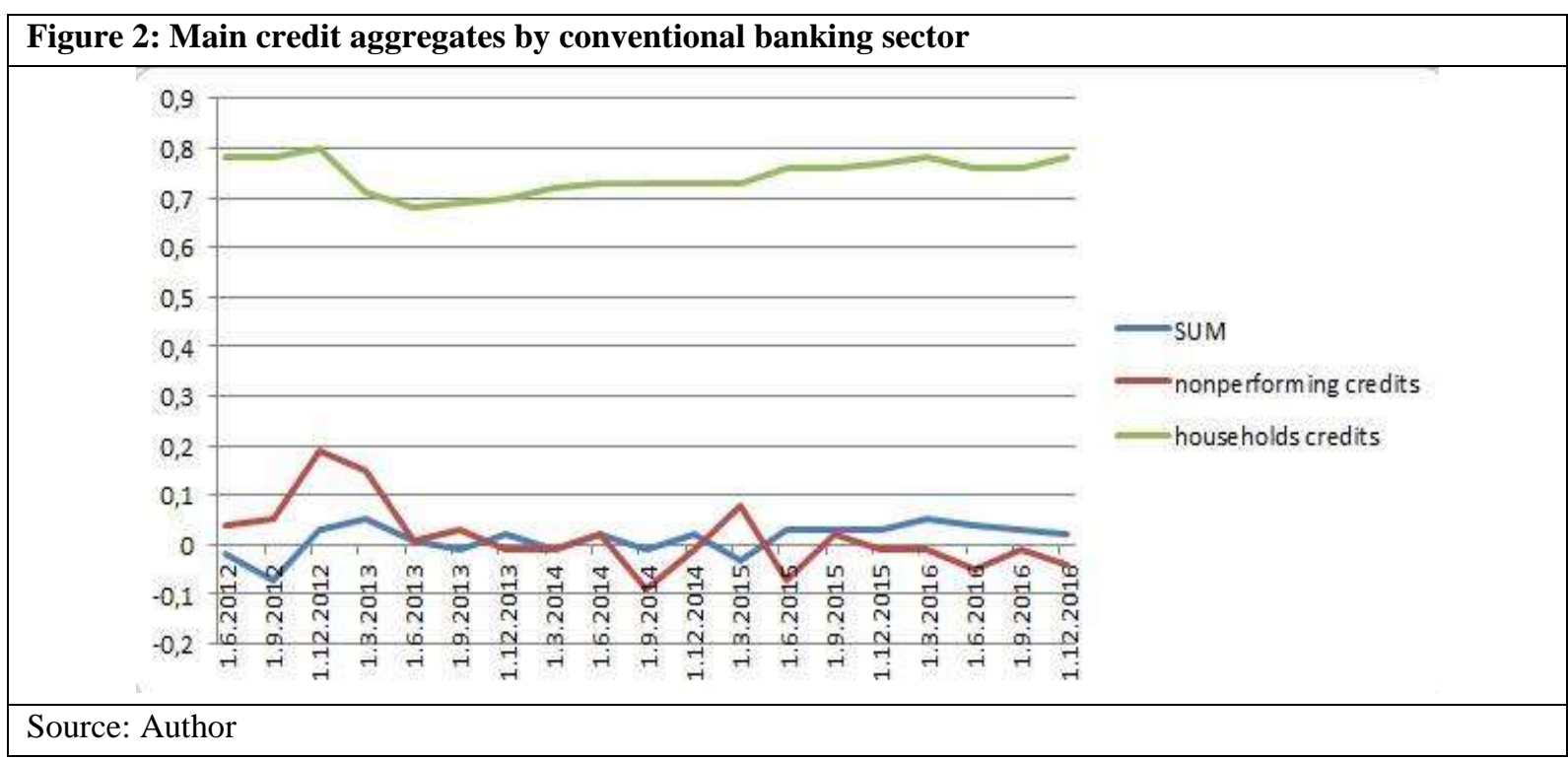




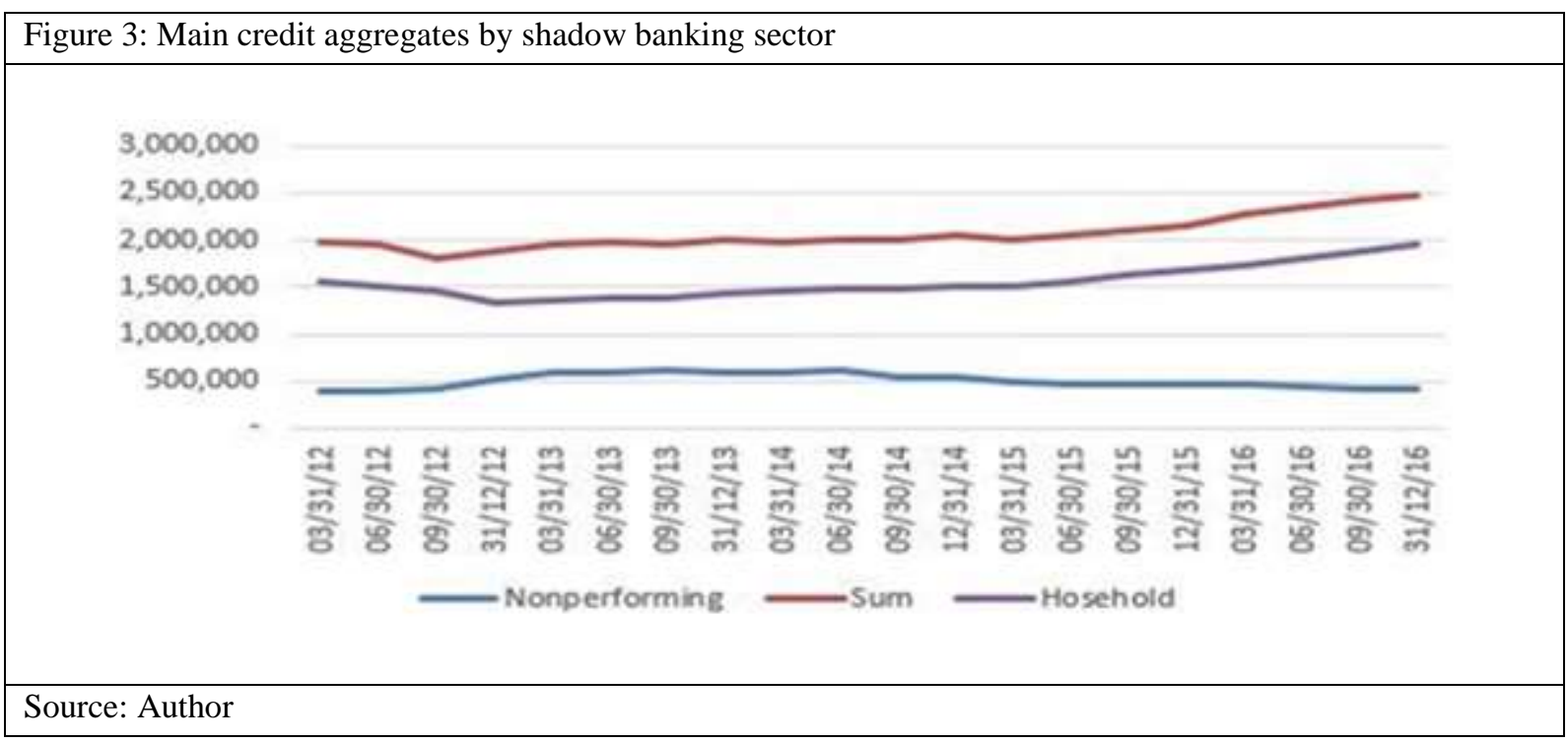

Banks'behavior to introduce financial innovation, especially when in financial markets' interest rates are negative or close to 0 , follows a conscious violation by moving deposits to shadow financial sector's credit institutions even in most cases violate the liquidity management regulations.

Working under the Currency board, the Bulgarian banking system is highly regulated and the central bank is limited to using a single tool - the mandatory minimum reserves. The change in the system of taxation of income and profits in proportion to the progressive tax rate of $10 \%$ trigger implementation of the "paradox of Keynes' for saving, which loaded the system with excess liquidity. An elevated criterion for access to credit in a crisis restricts the activities of banks to banking services and loans primarily to borrowers in the gray zone of the economy and directs them to the area of shadow banking.

The requirement for registered capital and funding sources in both types of banking is clearly defined with transparent sources and restrictions on crossing the minimum limit. The difference between the two sectors lies in the ability to attract deposits on open financial markets, which is why financial Institution of the informal banking sector attract resources through equity shares and contributions, but not as deposits of individuals and companies.

As a consequence of the above, and the analysis (Stavrova, 2012, Stavrova 2013, Stavrova \& Zlateva, 2016) and comparison of major credit performance of the two types of banking systems, respectively, Figure 1 and Figure 2 give way to formulate some basic differences and similarities:

The processes of global financial and economic development have reached a varying degree, the direction of development and the residual effects both on the synchronous functioning of the banking and non-banking sectors as inseparable parts of the financial system. While significant deviations from the mean represented as fluctuations and the peak in the variable "rate of increase in problem loans" in the third quarter of 2015, which noted the conventional banking sector, the same time interval banking sector shows a systematic, offensive upward development. The explanation of this trend is the specific feature of the currency board system, which allows bankruptcies of banks and prohibits the central bank to be a lender of last resort. This is the reason for the significant amount -5592690000 BGN, which is referred to as an increase in non-performing bank loans in the aforementioned period. During the same period, the conventional banking system has a symbolic rate of increase or decrease in the provision for new loans. This process may in each case be assessed as risk-sharing and transferring a system of shadow banking which creates a dangerous precedent for a new credit bubble.

Undoubtedly and significantly, the advantage that ensures the functioning of the shadow banking sector is the possibility of regulatory arbitrage - a considerably simplified licensing procedure, limited requirements for professional expertise of management Undoubtedly and significantly, the advantage that ensures the functioning of the shadow banking sector is the possibility of regulatory arbitrage - a considerably simplified licensing procedure, limited requirements for professional expertise of management, the independence of decision-making without coordination with the regulatory authority. 
The reporting activity is also simplified - instead of the monthly statements provided by traditional banks, credit institutions submit quarterly data., the independence of decision-making without coordination with the regulatory authority. The reporting activity is also simplified - instead of the monthly statements provided by traditional banks, the credit institutions submit quarterly data. This simplified procedure spur market participation of the non-banking sector and this makes it significantly more effective compared to the conventional banking sector.

Another important difference between conventional and shadow banking is that it provides an opportunity for gains from specialization in the financial intermediate and receiving the benefits of products' specialization in one segment of the financial market. From this, the realization of economies of scale is made possible by learning, and improving offering specialized credit in specific forms of credit intermediation functions. Alternative forms of credit intermediation are widely represented in the form of leasing in co-operation with car and industrial equipment manufacturers and dealers, purchase of debt commitments such as factoring and franchising, etc.

The customers of non-banking credit institutions are looking to borrow a much smaller amount than the banks would have made. The average value of the loans granted by its company is about BGN 700 and the maximum amount that can be borrowed - BGN 2,500. Thus as a result, they fill the consumer micro-credit niche, which is not as attractive and profitable for the banks and until recently this kind of lending was offered by illegal lenders.

A key advantage of shadow banking companies is that their operations are really negotiated short-term - usually the time between bidding and receiving is at most a few days and usually up to several hours. Unlike banks, bureaucratic procedures are limited to a minimum, loans are available at home, on the phone, and recently online. Thus, their services can benefit households and firms in remote areas where branches of conventional banks do not operate. An important advantage is that non-bank institutions are more flexible in terms of proof of income and past credit history, which is key to the majority of the population which works in the gray and no-tax pay economy in Bulgaria.

Finally, it should be underlined the special social role of the informal banking sector, namely providing accelerated access to loans to individuals and companies that cannot meet the high requirements for obtaining loans put up by their conventional banks. These small-volume loans, albeit expensive enough, as the new credit agreements are used to solve the urgent needs of households. A steady growth trend shows that this sector is represented by a relatively stable volume of loans and a continuously increasing importance in the credit market segment as a whole.

\section{Conclusion}

As, seen above, and in the resulting analytical comparison between two sectors - the conventional banking and the shadow banking sector, both are in a sharp competitive game for the same group of users, these sectors carry differently the ways to structure the fluctuations experienced by the nonfinancial sector during the global financial and economic crisis. Although the efforts of financial and political authorities were directed exclusively to the stability of the conventional banking sector, this same sector, although in arrears, suffered considerable losses that caused the banks to fail and hence shake the banking system as a whole.

At the same time the shadow banking sector going through all these events prepared and generated high levels of risk in the price of credit resources, and therefore not suffered any significant losses.

During the same period the conventional banking system has a symbolic rate of increase or decrease in the provision of new loans. This process may in each case be assessed as risk-sharing and transferring a system of shadow banking, which creates a dangerous precedent for a new credit bubble. These trends of development, except that those that register, need to be monitored, controlled and guided to limit the possibilities of occurrence of new crisis fluctuations. Development of an international framework for the operation and oversight of shadow banking will limit the realization of regulatory arbitrage and hence - the possibility of concentrating significant risks in some regions.

\section{References}

Ganchev, G. (2015). Towards Holistic Theory of Money: Overcoming Twentieth Century Neoclassical Monetary Paradigm. Economic Studies, 4, 3-24.

Patonov, N. (2013). Searching for a Restraint on the European Leviathan. Scientific Annals of the "Alexandru Ioan Cuza, 60/2, 315-330. doi:http://saaic.feaa.uaic.ro/index.php/saaic/article/view/106 
Stavrova, E. (2012). Efficiency of the Banking Industry - Relationships and Dependencies Bulgaria, Albania - Comparative Study. Retrieved March 31, 2017, from https://www.researchgate.net/profile/Elena_Stavrova

Stavrova, E. (2013). Financial Security Net as a Factor Banking System Stability,. Retrieved March 31, 2017, from https://www.researchgate.net/

Stavrova, E., \& Zlateva, D. (2016). ICIMSC 2016 (1st ed.). Financial Innovations and Banking Value Chain Chanels of distributions, Lisbon, PR: Universidade Europeia. Doi: e-ISBN: 978-989-20-6718-6

Tanchev, S. (2016). Consumer tax system of Bulgaria in term of economics growth and crisis. Economic Thought, 4, 85-105.

Tsenkov, V. (2015). Crisis influences between developed and developing capital markets - the case of central and eastern European countries. Economics Studies, (3), 71-108.

Tsenkov, V., \& Georgieva, S. (2016). Market efficiency in post-crisis period in the case of Central and Eastern Europe. Cambridge Journal of Education and Science, 1/15(III). 